Seyahat ve Otel İşletmeciliği Dergisi/

Journal of Travel and Hospitality Management

14 (3), 2017, 53-73.

Gönderim Tarihi:26.07.2016

Kabul Tarihi:18.04.2017

\title{
Termal Otel İşletmelerinde Personel Bulma, Seçme ve Personeli İşe Yerleştirme Sürecindeki Uygulamalar ve Sorunlar Üzerine Bir Araştırma: Afyonkarahisar Örneği
}

\section{A Research on Applications and Problems in the Processes of Personnel Recruitment, Selection and Placement in Thermal Hotels: The Case of \\ Afyonkarahısar}

Doç. Dr. Elbeyi PELIT

Afyon Kocatepe Üniversitesi

Turizm Fakültesi

E-posta:elbeyipelit@aku.edu.tr Orcid Id:0000-0002-6418-801X
Doç. Dr. Hasan Hüseyin SOYBALI

Afyon Kocatepe Üniversitesi

Turizm Fakültesi

E-posta: hsoybali@aku.edu.tr

Orcid Id:0000-0002-5929-0933

\author{
Arş.Gör. Serkan AK \\ Sinop Üniversitesi \\ Turizm İşletmeciliği ve Otelcilik Yüksekokulu \\ E-posta:serkanak@sinop.edu.tr \\ Orcid Id:0000-0002-9094-4202
}

\section{Öz}

$\mathrm{Bu}$ araştırmanın amacı; önemli bir turizm işletmesi türü olan termal otel işletmelerinin, termal otel olmalarının getirdiği özellikler de dikkate alınarak personel bulma, seçme ve personeli işe yerleştirme süreçlerinde hangi uygulamalara başvurduklarını ortaya koyarak, konuyla ilgili sorunların belirlenmesidir. Bu çerçevede Türkiye'nin önemli bir termal turizm destinasyonu olan Afyonkarahisar'daki beş yıldızlı termal otel işletmelerinde bir araştırma gerçekleştirilmiş olup, söz konusu işletmelerin personel bulma, seçme ve personeli işe yerleştirme süreçlerinin belirlenmesinde yarı yapılandırılmış görüşme yönteminden faydalanılmıştır. Araştırma sonucunda, termal otel işletmelerinin bu süreçlere ilişkin uygulamalarında literatürdeki otel işletmeleri üzerine yapılmış araştırmaların sonuçlarına da yansıyan birtakım sorunların (nitelikli personel bulamama, turizm eğitimi almış personel adaylarına gerekli önemin verilmemesi vb.) olduğu tespit edilmiştir.

Anahtar Kelimeler: Personel bulma, Personel seçme, Personeli işe yerleştirme, Termal otel işletmeleri, Afyonkarahisar.

\begin{abstract}
The purpose of this study is to determine issues related to personnel recruitment, selection and placement processes of thermal hotels, which are among the most important types of tourism enterprises, by taking account of thermal hotels' qualities. In this context, this study was implemented in the five-star thermal hotels in Afyonkarahisar, an important thermal tourism destination of Turkey, and a semi-structured interview method was used to determine the personnel recruitment, selection and placement processes of the thermal hotels. As a result of the research, it was found that there are some problems related to these processes (such as not being able to find qualified personnel, not giving enough importance to tourism educated personnel) as reflected in the results of the researches on the hotel enterprises in the literature.
\end{abstract}

Keywords: Personnel recruitment, Personnel selection, Personnel placement, Thermal hotels, Afyonkarahisar. 


\section{Giriş}

Hayatın her alanına yansıyan bilgi ve teknolojideki gelişmeler, hangi alanda faaliyet gösterirse göstersin işletmeleri bu gelişmelere hâkim daha kaliteli insan kaynağına sahip olmaya zorlamaktadır (Adıgüzel, 2009: 243). Bu bağlamda yeni veya mevcut pozisyonları doldurmak için personelin bulunması ve seçilmesi; boyut, yapı veya etkinlik ne olursa olsun tüm turizm işletmelerinde de insan kaynakları yönetimi faaliyetlerinin önemli bir unsurudur (Nickson, 2007: 88). Nihayetinde bir işletmenin ömrünü planlayan, tasarlayan, tamamlayan, sürdüren ve sona erdiren bir unsur olan insan kaynağı; işletmeler için büyük önem arz etmektedir (Şenyücel, 2009: 11). Ayrıca küresel rekabetin hızla arttığı günümüz iş ortamında insan kaynağı, işletmeler için en değerli ve ikame edilemez rekabet unsuru haline gelmektedir (Erdil ve Özutku, 2013: 3). Bu bağlamda turizm işletmelerinin hizmet sektöründe yer alması sebebiyle bu husus turizm sektöründe daha da ön plandadır. Çünkü turizm sektörünü diğer sektörlerden ayıran en önemli özelliklerden biri, sektörün emek-yoğun bir yapıya sahip olmasıdır. Bu durum da turistik faaliyetlerde ve ürün oluşturmada kaliteye ulaşabilmenin en önemli yollarından birinin kalifiye insan kaynağına sahip olmaktan geçtiğini ortaya koymaktadır (Şit, 2016: 115-116). Turizm sektöründe başarı, işletmenin amacına ulaşmasına yardımcı olan personelinin kalitesine ve etkin yönetimine bağlıdır (Atoyan, 2015: 1). Bu yüzden turizm işletmelerinde ve özellikle bir konaklama işletmesi olan otel işletmelerinde insan gücünden yararlanma ihtiyacı, hala önemini kaybetmeyen bir zorunluluk ve gereklilik durumundadır (Özgan ve diğ., 2010: 30).

Termal otel işletmeleri de hem tıp biliminin termal turizm ile ilgili gelişmelerini bünyesinde toplayan hem de turizmin gerektirdiği konaklama ve boş zamanları değerlendirme gibi hizmetleri sunan işletmeler olmaları sebebiyle diğer otel işletmelerine kıyasla daha fazla ve daha farklı alanda personele intiyaç duymaktadır (Aslan, 2015: 27). Söz konusu bu personel ihtiyaçları karşılanırken insan kaynakları yönetimi faaliyetlerinin etkin ve başarılı bir şekilde uygulanması gerekmektedir. Bu bağlamda personel bulma, seçme ve personeli işe yerleştirme; insan kaynakları yönetiminin diğer faaliyetlerini ve örgütsel başarıyı etkileyen önemli bir işlev olarak ortaya çıkmaktadır (Acar, 2010: 85). Çünkü bu işlev kapsamında önemli olan, boş pozisyonlara işgücü bulmak değil; doğru işe doğru personeli bulabilmektir (Erdem ve Gezen, 2014: 21). En iyi ve en doğru personeli işe almak ise belirli planlamalar ve rasyonel biçimde yapılandırılmış bir süreç gerektirmektedir (Çolak, 2010: 86). Bununla birlikte işletmeler doğru işe doğru personeli bulamazlarsa işletmenin misyonunu, vizyonunu ve uzun vadeli hedeflerini kapsamlı bir şekilde yerine getiremeyeceklerdir (Mathis ve Jackson, 2008: 226). Ayıca turizm sektöründeki işletmelerde personelin müşterilere kaliteli ve verimli bir hizmet verebilmeleri için insan kaynaklarının doğru bir şekilde seçilmesi daha büyük önem arz etmektedir (Şimşek ve diğ., 2014: 147).

Turizm sektörünün taşıdığı çeşitli özellikler (uzun çalışma saatleri, kısıtlı sosyal olanaklar, sezonluk çalışma, düşük ücretler vb.) nedeniyle turizm işletmelerinde personel devir hızı, genelde diğer işletme türlerine oranla daha yüksektir (Erdem ve Gezen, 2014: 20; Pelit ve Kılıç, 2012: 126). Yüksek personel devir hızı ise turizm ve özellikle otelcilik sektöründe en önemli sorunlardan birini oluşturmaktadır (Cho ve diğ., 2006: 267). Çünkü otel işletmelerinde çalışan personelin işten ayrılması, yeni personel intiyacından dolayı personel seçimi konusunda daha fazla zaman harcanmasına ve maliyetlerin artmasına yol açmaktadır (Akova ve diğ., 2015: 88). Ancak bu noktada ironik bir biçimde, turizmde personel devir hızının yüksek olmasında yukarıda sıralanan faktörler etkili olmakla birlikte işletmelerin yanlış işe alım politikalarının da sorunun önemli bir parçası olduğu düşünülmektedir (Erdem ve Gezen, 2014: 20). Bu noktadan hareketle değerlendirildiğinde, yanlış işe alım politikaları neticesinde işe yerleştirilen 
ancak işe uygun olmayan personelin geliştirilmesi de turizm işletmeleri için oldukça güç ve maliyetlidir. Buna karşın iyi seçilmiş bir personel, eğitimler ile daha yeterli hale gelebilmekte; eksikleri olsa bile bunları giderebilmektedir (Tütüncü ve Demir, 2002: 10). $\mathrm{Bu}$ bağlamda özetle doğru personelin işe alınması; emek yoğun bir sektör olan turizmde insan kaynağından verimli olarak yararlanmak, personel devir hızını düşürmek ve personel eğitim masraflarını azaltmak için son derece önemlidir (Akoğlan, 1998: 26).

Bu kapsamda sektörün değişik işletme türlerinde bu konuyla ilgili mevcut durumunun ve sorunların belirlenerek öneriler geliştirilmesi, bu alandaki gelişime katkı sağlayacak unsurlardan olacaktır. Bu doğrultuda araştırmada, termal otel işletmelerinin termal otel olmalarının getirdiği özellikler de göz önünde bulundurularak personel bulma, seçme ve personeli işe yerleştirme süreçlerinde başvurdukları uygulamalar incelenerek, tespit edilen birtakım sorunlarla birlikte işletmelerin söz konusu bu süreçler kapsamında karşılaştığı zorluklar ortaya konularak öneriler geliştirilmiştir.

\section{Personel Bulma, Seçme ve Personeli İşe Yerleştirme Uygulamaları ve Termal Otel İşletmeleri Açısından Önemi}

İşletmelerde insan kaynakları yönetiminin temel işlevleri arasında yer alan personel bulma, seçme ve personeli işe yerleştirme işlevi; bazen sadece personel seçimi olarak ele alınmakta olup bu işlevin ilk adımı olan personel bulma süreci göz ardı edilmektedir (Pelit, 2015: 86). Personel bulma, nitelikli başvuru sahiplerinin bulunması ile ilgilidir ve örgütsel işler için nitelikli başvuru havuzları üretme sürecidir (Mathis ve Jackson, 2011: 194). Personel bulma, işletmenin açık pozisyonlarına başvuranların bulunması ve/veya çekilmesi anlamına gelmektedir (Dessler, 2013: 146). Personel bulma süreci, işletmedeki açık işlerin saptanması ile birlikte bu işlerin analiz edilip iş gerekleri ve iş tanımlarının yapılması neticesinde işlere uygun nitelikteki personelin nereden ve nasıl sağlanacağını belirlenmesi sonrasında işletme içinden veya dışından personele ulaşılması ile bir aday havuzunun oluşturulması aşamalarından oluşmaktadır (Ayan, 2011: 115-116). Ancak günümüzde işletmeler, personel bulma sürecinde özellikle işgücü piyasasının sürekli değiştiğinin farkında olmalıdır (Dias, 2011: 31). Örneğin, işgücü piyasasını oluşturan bireylerin artık işle ilgili farklı değer ve beklentileri bulunmaktadır. Daha yüksek maaş istekleri, örgütsel karar alma sürecine katılma olanaklarının bulunmasına önem vermeleri, daha saygılı ve adil davranılmasını beklemeleri, çalışma sürelerinin aileleri ve kişisel yaşamları üzerindeki etkileri konusunda endişe duymaları, bu değişen değer ve beklentiler kapsamında dikkat çekmektedir (Burke ve $\mathrm{Ng}$, 2006: 86). Nitekim işgücü piyasasındaki yaşanan değişimlerle birlikte (Temizkan, 2015: 281-282) nitelikli personel bulmanın zorluğunun (Keskin, 1998: 49) personel bulma sürecinde işletmeleri zor duruma soktuğu düşünüldüğünde, otel işletmelerinde halen ihtiyaç olan personelin belirlenmesinde amatör tutumların sergilenmesi (Çabuk, 2005: 115-116) ve intiyaç duyulan personeli bildirmede diğer departmanlar ile insan kaynakları departmanı arasında sistematik bir düzenin olmaması (Erdem, 2002: 161), otel işletmelerindeki personel bulma sürecinin etkinliğini ve ciddiyetini azaltan faaliyetler olarak göze çarpmaktadır. Ayrıca otel işletmelerinin personel bulma aşamasında bireysel başvuruları ve örgüt içi kaynakları yoğun bir şekilde tercih etmesinin (Akbaba ve Günlü, 2011: 221) yanı sıra; Türkiye İş Kurumu, eğitim kurumları, sendikalar ve internet gibi personel bulma kaynaklarını ihmal etmesinin (Akbaba ve Günlü, 2011: 219; Bilgiçli, 2010: 95; Temizkan, 2010: 163), personel bulma süreçlerinde otel işletmelerinin uyguladığı yanlış stratejilerin mevcut olduğunu işaret ettiği aşikârdır. 
Personel bulma çabaları sonucu bir aday havuzu oluşturulduktan sonra, sıra işe alınacak uygun personelin seçimine gelmektedir (Acar, 2010: 129). Personel seçme, başvuru sahiplerinin veya adayların hangilerinin işe alınması gerektiğine karar verilmesiyle ilgili bir süreçtir (Armstrong ve Taylor, 2014: 226). Bu süreçte etkili seçim yaklaşımlarının geliştirilmesi, doğru işe doğru personel ilkesi için çok önemlidir (Chien ve Chen, 2008: 280). Otel işletmelerinde de personel seçme sürecinde işe uygun aday ilkesinden hareket edilmesi gerekmektedir. Aksi takdirde bu konuda yapılacak bir hata bir otel içerisinde konaklayan müşterilerin hizmet kalitesi ve buna bağlı olarak işletmeye ilişkin imaj algılaması üzerinde olumsuz bir etki oluşturabilmektedir (Gümüş ve diğ., 2010: 1). Ayrıca işletmeler tarafından; personel seçme sürecinde, sürecin etkin ve rasyonel bir şekilde işlemesini etkilemekte olan işgücü planları, iş analizleri, performans değerleme, ahlaki değerler ve personel bulma aşamasına verilen önem gibi birtakım örgütsel kısıtlayıcılar (Kozak, 2009: 106) göz önünde bulundurularak hareket edilmelidir. Ancak otel işletmelerinde kalitesiz personelin seçilmesinin daha kolay ve masrafsız algılanması (Bilgiçli, 2010: 97; Özdemir ve diğ., 2015: 137), gerçekleşen ayrımcılık ve hemşehricilik uygulamaları (Yeşiltaş ve diğ., 2010: 192-193; Yeşiltaş ve diğ., 2012: 99; Temizkan, 2010: 163-166; Demir, 2011: 781), turizm eğitimi almış insanların turizm tecrübesine sahip insanlara nazaran daha az tercih edilebilir nitelikte olarak değerlendirilmesi (Chan ve Kuok, 2011: 429; Şimşek ve diğ., 2014: 163) gibi etmenler; dikkat edilmesi gereken unsurların öneminin algılanmasına ve işe uygun aday ilkesinin benimsenmesine olanak tanımamaktadır. Otel işletmelerince personel seçme sürecinde görüşme, iş başvuru formu, referans değerlendirme yöntemlerinin yoğun bir şekilde uygulanması (Akoğlan, 1998: 27; Akbaba ve Günlü, 2011: 221; Chan ve Kuok, 2011: 429); işletmelerde halen süregelmiş personel seçme yöntemlerinin tercih edildiğini ve daha kapsamlı (biyografik yöntemler gibi) yöntemlere başvurulmadığını göstermektedir.

Personel seçiminin nihai amacı, kişinin doğru işe yerleştirilmesidir. Bir personelin bir işe ne kadar iyi uyum sağladığı, işin niteliğini ve kalitesini etkilemekte bunun yanı sıra bireyi çalışma hayatına hazırlamak için gereken eğitim ve işletme giderlerini de etkilemektedir (Mathis ve Jackson, 2011: 214). Bu bağlamda personel bulma ve seçme süreçlerinden sonra işe alma sürecinin son aşaması olan kişinin işe yerleştirilmesi; işe başlayanların bireysel yeteneklerini, bilgilerini, becerilerini, tercihlerini, ilgilerini ve kişiliklerini işle eşleştirme eylemidir (Karacaoğlu, 2013: 192). İşe yeni başlayan personelin kendi haline bırakılmaması gerekmektedir. Yeni işe başlayan personel, hem iş arkadaşları ve ilgili yöneticilerle tanıştırılmalı hem de çalışma ortamı ve işyeri kuralları gibi konularda bilgilendirilmelidir (Çolak, 2010: 106). Bu durum personelin işletme ile bütünleşmesine olanak sağlamaktadır. Bu süreçte bütünleşmenin tam olarak sağlanabilmesi için işletmenin stratejik amaçları, misyonu, vizyonu, kültürü gibi kavramları da personele açık bir şekilde aktarılmalıdır. Bunun yanı sıra; personele bu kavramlara uygun davranışlar sergilemesi gerektiği belirtilmeli ve personel tarafından uygulaması sağlanmalıdır. Esasında bu husus insan kaynakları yönetiminin önemli diğer bir işlevi olan hizmet içi eğitiminin ilk ve önemli bir basamağını oluşturan oryantasyonla da bütünleşik bir işleyişe sahiptir. Bu süreç dâhilinde çalışma şartlarının personel adaylarına doğru ve eksiksiz bir şekilde anlatılmaması (Kolu, 2006: 90-91), ağır çalışma şartlarına ayak uyduramayacak personelin işe yerleştirilmesi (Boz, 2006: 59), işe uygun olmayan personelin birtakım nedenlerden dolayı (pozitif ayrımcılık, hemşehricilik gibi) işe yerleştirilmesine çalışılması (Yeşiltaş ve diğ., 2012: 99; Demir, 2011: 781) ve aynı görevdeki personel arasında personel lojmanlarındaki ağırlama şartlarında oluşabilecek farklılıklar (Çavdar ve Çavdar, 2010: 91); personeli işe yerleştirme sürecinde yaşanan sorunların ve yapılan hataların bazılarını oluşturmaktadır. Bütün bu personel bulma, seçme ve personeli işe yerleştirme uygulamaları; günümüzde çoğu sektördeki işletmeler için sürdürülebilir olmanın 
gereğidir. Nitekim özellikle turizm sektörünü oluşturan otel işletmeleri açısından bu uygulamaların ve süreçlerin önem derecesi, işletmedeki hizmetlerin üretiminin yoğun olarak insan unsuruna dayanmasından dolayı daha üst düzeydedir. Bu bağlamda, dinlenme ve eğlence amaçlı seyahatlerin halen turistler açısından en önemli seyahat motivasyonu olduğunun bilinmesiyle birlikte son yıllarda değişik turizm türlerinin öne çıktığı görülmektedir. Bu turizm türlerinden birisini de sağlık amaçlı yapılan seyahatler oluşturmaktadır. Günümüzde sağlık turizminin temel öğesini termal turizm, termal turizmin temel öğesini ise termal otel işletmeleri olarak belirtmek mümkündür (Erdem ve diğ., 2015: 254).

Termal otel işletmeleri; yapımı, işletilmesi, pazarlanması, tanıtılması ve yapılan diğer uygulamalar yönünden diğer otel işletmelerine göre farklı özellikler arz etmektedir. Bu bağlamda termal otel işletmelerini farklı kılan bu özellikler arasından insan kaynaklarını etkileyenleri ve insan kaynaklarıyla ilgili olanlarına değinmekte fayda görülmektedir. Buna göre diğer turizm işletmelerinden farklı olarak termal otel işletmelerinde, hasta ve sağlıklı kişilerin bir arada konaklamalarından dolayı çok farklı yapıda turist ve küristin (herhangi bir tedavide uygulanan kürden yararlanan kimse) intiyaçlarını karşılayabilecek nitelikte personel istihdam edilmektedir (Özbek, 1991: 16). Örneğin, termal otel işletmelerinde rekreasyon alanlarını canlandıracak; çeşitli aktiviteleri yönetebilecek ve bu konuda bilgi verebilecek animatörlerin istihdam edilmesi gerekmektedir. Bununla birlikte termal otel işletmelerinde normal turizm personeli dışında; uzman doktor, fizyoterapist, psikiyatrist, hemşire, diyetisyen, masör gibi çeşitli sağlık personeli de istihdam edilmektedir. Bu nedenle; güler yüzlü, nitelikli, insanı seven ve hasta psikolojisinden anlayan bir sağlık personeli kadrosu, termal otel işletmelerinde önem taşımaktadır. Aynı zamanda istihdam edilen sağlık personelinin küristlerle uzun süre (2-3 hafta) sürekli bir arada bulunmaları sebebiyle mesleki deneyimlerinin yanında müşterilerle yüz yüze ilişki halinde bulunan diğer turizm personelinin sahip olması gereken niteliklere de sahip olması gerekmektedir. Termal otel işletmelerinin insan kaynaklarını etkileyen diğer özelliklerini, doluluk oranı en yüksek turizm işletmelerinden biri olmaları ve tüm yıl boyunca açık olmaları şeklinde belirtilmek mümkündür (Aslan, 2015: 27-39). Doluluk oranlarının yüksek olması ve tüm yıl hizmet vermeleri, diğer otel işletmelerine oranla termal otel işletmelerinin daha fazla personeli istihdam etmesini gerektirmektedir.

Nihayetinde termal otel işletmelerinin alt yapı standartlarının oluşturulması, sunulan hizmetin kalitesi açısından yeterli olmamaktadır. Termal otel işletmelerinde hizmeti sunmakta olan personelin nitelik ve nicelik yönünden var olan standartlara uyması gerekmektedir. Oteldeki personel kadroları; iyi eğitilmiş, yaptıkları iş ile ilgili temel bilgilere sahip ve sundukları hizmetin diğer turizm hizmetlerinden farkını bilen kişilerden oluşmalıdır (Kök, 2013: 26). Termal otel işletmeleri, termal tedavinin gerektirdiği bilgi ve deneyime sahip tıp personeli ile konaklama hizmetlerini sanitasyon kuralları içinde yürütebilecek kalifiye elemanlarla amaçlarına daha çabuk ulaşabilmektedirler. Bunun için, hizmeti sunan personelin; meslekleri ve turizm olgusu göz önünde bulundurularak belirlenen niteliklere sahip olması büyük önem taşımaktadır. Termal otel işletmelerinde personel seçimi sırasında belirli niteliklerin aranması halinde gelecekte ortaya çıkabilecek sorunlar önemli ölçüde azaltılmış olacaktır (Aslan, 2015: 39). Bu kapsamda termal otel işletmelerinin diğer otel işletmesi türlerine göre birtakım farklılıklar taşımasından yola çıkarak literatürdeki otel işletmeleri üzerine yapılan araştırmalarda vurgulanan personel bulma, seçme ve personeli işe yerleştirme uygulamalarında karşılaşılan sorunları özetleyen aşağıdaki tabloyu incelemek araştırmanın bulgularıyla daha önceki araştırmaların bulgularını karşılaştırmak açısından faydalı olacaktır. 
Tablo 1: Otel İşletmelerinde Personel Bulma, Seçme ve Personeli İşe Yerleştirme Sorunları

\begin{tabular}{|c|c|c|}
\hline \multirow{6}{*}{ 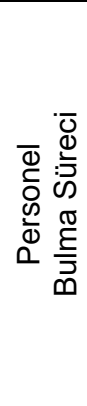 } & İşgücü piyasasındaki yaşanan değişimler & Temizkan, 2015. \\
\hline & Nitelikli personel bulmanın zorluğu & Keskin, 1998. \\
\hline & $\begin{array}{l}\text { İhtiyaç olan personelin belirlenmesinde amatör tutumların } \\
\text { sergilenmesi }\end{array}$ & Çabuk, 2005. \\
\hline & $\begin{array}{l}\text { İhtiyaç olan personeli bildirmede departmanlar ile insan } \\
\text { kaynakları departmanı arasında sistematik düzenin olmaması }\end{array}$ & Erdem, 2002. \\
\hline & $\begin{array}{l}\text { Süregelmiş personel bulma yöntemlerinin (bireysel başvuru, } \\
\text { örgüt içi kaynaklar) yoğun bir şekilde uygulanması }\end{array}$ & $\begin{array}{l}\text { Akbaba ve Günlü, } \\
2011 .\end{array}$ \\
\hline & $\begin{array}{l}\text { İş ve işçi bulma kurumu, eğitim kurumları, sendikalar ve internet } \\
\text { gibi personel bulma kaynaklarının ihmal edilmesi }\end{array}$ & $\begin{array}{l}\text { Akbaba ve Günlü, } \\
\text { 2011; Bilgiçli, 2010; } \\
\text { Temizkan, } 2010 .\end{array}$ \\
\hline \multirow{6}{*}{ 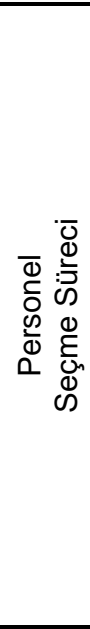 } & $\begin{array}{l}\text { Kalitesiz personelin seçilmesinin daha kolay ve masrafsız } \\
\text { algılanması }\end{array}$ & $\begin{array}{l}\text { Bilgiçli, } 2010 ; \\
\text { Özdemir ve diğ., } \\
2015 .\end{array}$ \\
\hline & $\begin{array}{l}\text { Personel seçimini yapan kişilerin kendi eğitim düzeylerinde olan } \\
\text { personeli seçmesi }\end{array}$ & Örücü, 2002. \\
\hline & $\begin{array}{l}\text { Seçilecek personelde eğitim yerine deneyimin daha önemli bir } \\
\text { seçme kriteri olması }\end{array}$ & $\begin{array}{l}\text { Chan ve Kuok, } \\
\text { 2011; Şimşek ve } \\
\text { diğ., 2014. }\end{array}$ \\
\hline & $\begin{array}{l}\text { Süregelmiş personel seçme yöntemlerinin (görüşme, iş başvuru } \\
\text { formu, referans değerlendirme) yoğun bir şekilde uygulanması }\end{array}$ & $\begin{array}{l}\text { Akoğlan, 1998; } \\
\text { Akbaba ve Günlü, } \\
2011 \text {; Chan ve } \\
\text { Kuok, 2011. }\end{array}$ \\
\hline & $\begin{array}{l}\text { Personel seçme aşamasında gerekli olmayan, ayrımcılığa tabi } \\
\text { tutulabilecek bilgilerin istenmesi }\end{array}$ & $\begin{array}{ll}\text { Yeşiltaş ve diğ., } \\
\text { 2010; } & \text { Temizkan, } \\
2010 . & \end{array}$ \\
\hline & Siyasi ayrımcılık, hemşehricilik uygulamaları & $\begin{array}{l}\text { Yeşiltaş ve diğ., } \\
\text { 2012; Demir, 2011. }\end{array}$ \\
\hline \multirow{4}{*}{ 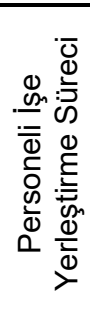 } & Çalışma şartlarının doğru ve eksiksiz bir şekilde anlatılmaması & Kolu, 2006. \\
\hline & $\begin{array}{l}\text { Ağır çalışma şartlarına ayak uyduramayacak personelin işe } \\
\text { yerleştirilmesi }\end{array}$ & Boz, 2006. \\
\hline & $\begin{array}{l}\text { İşe uygun olmayan personelin birtakım nedenlerden dolayı } \\
\text { (pozitif ayrımcılık, hemşehricilik gibi) işe yerleştirilmesine } \\
\text { çalışılması }\end{array}$ & $\begin{array}{l}\text { Yeşiltaş ve diğ., } \\
\text { 2012; Demir, } 2011 .\end{array}$ \\
\hline & $\begin{array}{l}\text { Aynı görevdeki personel arasında, personel lojmanlarında } \\
\text { ağırlama şartlarında oluşabilecek farklılıklar }\end{array}$ & $\begin{array}{l}\text { Çavdar ve Çavdar, } \\
2010 .\end{array}$ \\
\hline
\end{tabular}

Tablo 1 incelendiğinde otel işletmelerinde; personel bulma, seçme ve personeli işe yerleştirme süreçlerinde ayrı ayrı birçok sorunun yaşandığı, konuyla ilgili çalışmalarda göze çarpmaktadır. Bu kapsamda söz konusu bu sorunların termal otel işletmeleri açısından da değerlendirilerek ortaya konulması ve bu doğrultuda çözüm önerileri getirilmesi önem taşımaktadır. Nitekim Tablo 1 dâhilindeki personel bulma, seçme ve personeli işe yerleştirme konusunu ele alan araştırmaların sonuçları, genel olarak tüm otel işletmesi türlerini kapsar niteliktedir. Bu yüzden değinilen bu sorunların farkındalığının araştırmacılar ve otel işletmeleri tarafından algılanabilmesi bakımından konunun daha özele indirgenerek (termal otel işletmeleri veya diğer otel işletmesi türleri) araştırılması ve ortaya konmasının konuya yeni bir bakış açısı kazandıracağı, bununla birlikte otel işletmelerinin de konuya daha fazla ciddiyet ve hassasiyet göstermelerini sağlayacağı düşüncesi, bu araştırmanın hareket noktasını oluşturmaktadır. 


\section{Araştırmanın Yöntemi}

\subsection{Araştırmanın Amacı ve Önemi}

$\mathrm{Bu}$ araştırmanın amacı; termal otel işletmelerinin termal otel olmalarının getirdiği özellikler de dikkate alınarak önemli bir insan kaynakları yönetimi işlevi olan personel bulma, seçme ve personeli işe yerleştirme sürecindeki uygulamalarının belirlenerek konuyla ilgili sorunların ortaya konmasıdır. Söz konusu bu süreçler kapsamında termal otel işletmelerinin karşılaştığı sorunlar/zorluklar ortaya konularak ilgili taraflara öneriler geliştirilmesi, sürecin daha iyi yönetilmesi açısından önem taşımaktadır. Yine araştırmadan elde edilecek sonuçlar, özellikle bu konuyla ilgili turizm işletmeleri genelinde başvurulan uygulamaların ve süreç esnasında yaşanan sorunların, otel işletmesi türlerine göre farklılaşıp farklılaşmadığına olanak tanıyacak verileri ortaya koyması açısından da fayda sağlamaktadır. Bunun yanında bu konuyla ilgili termal otel işletmelerinde ve Türkiye'nin en önemli termal turizm destinasyonu olan Afyonkarahisar'da herhangi bir araştırma yapılmamış olması da bu çalışmayı diğer çalışmalardan farklı kılan hususlardandır.

\subsection{Araştırmanın Evreni}

Araştırma evrenini, zaman ve maliyet unsurlarının kısıtlayıcılığı nedeniyle ülkemizde yer alan tüm termal otel işletmelerine ulaşılmasının zorluğu düşünülerek ülkemizin en önemli termal turizm destinasyonu olan Afyonkarahisar'da faaliyet gösteren beş yıldızlı termal otel işletmeleri oluşturmaktadır. Araştırma evreninin Afyonkarahisar olarak seçilmesindeki temel etken, Afyonkarahisar'ın ülkemizdeki en fazla turizm işletme belgeli termal otel işletmesine ev sahipliği yapması (T.C. Kültür ve Turizm Bakanlığı, 2016) ve bunun da araştırma sonuçlarının genellenebilirliği açısından avantaj sağlayacağıdır. Bunun yanında araştırmanın sadece beş yıldızlı otel işletmeleri olarak sınırlandırılmasının nedeni ise gerek büyüklükleri ve gerekse kurumsallaşmaları nedeni ile personele yönelik araştırmalara önem vermeleri ve geri dönüşlerinin daha fazla olmasıdır.

Bu kapsamda araştırma evrenini oluşturan Afyonkarahisar merkez ve ilçelerde faaliyette bulunan beş yıldızı termal otel işletmelerinin tamamı (toplam on adet), araştırma kapsamında yer almayı kabul etmiş olup bu doğrultuda 01.05.201615.05.2016 tarihleri arasında araştırma evrenindeki tüm termal otel işletmelerinin insan kaynakları departmanı yöneticilerine ulaşıımıştır. Ayrıca araştırma evrenini oluşturan termal otellerde insan kaynakları departmanında çalışan kişi sayılarının farkılık göstermesi doğrultusunda daha anlamlı sonuçlar alabilmek adına her bir termal otel işletmesini temsil etmek üzere o otelin sadece en üst düzey insan kaynakları departmanındaki yöneticisiyle görüşülmüş ve görüşme yapılan yönetici sayısı da bu yüzden on ile sınırlı kalmıştır ki, belirtildiği gibi hali hazırda Afyonkarahisar'da (ilçelerde dâhil) faaliyette bulunan toplam on adet beş yıldızlı termal otel işletmesi vardır. Dolayısıyla evrenin tamamına ulaşılmıştır.

\subsection{Verilerin Toplanması ve Analizi}

Araştırma verilerinin toplanmasında, nitel veri toplama yönteminden faydalanmıştır. Konuyla ilgili yapılan çalışmalarda (Çabuk, 2005; Erdem, 2002; Kolu, 2006) genellikle nicel yöntemlere başvurulduğu göz önüne alındığında, bu araştırmanın özellikle nitel bir özellik taşıyan görüşme yöntemini barındırmasının yanında, otel işletmeleri tarafından tercih edilen personel bulma kaynakları ve personel seçme yöntemleri gibi verilerin elde edilmesine yer vermesinin, konunun daha derinlemesine incelenmesine 
avantaj sağladığını belirtmek mümkündür. Bu çerçevede araştırmada verilerin toplanmasında literatürde yer alan çalışmalardan (Çabuk, 2005; Erdem, 2002; Kolu, 2006; Ünal, 2006) ve konuyla ilgili uzmanlardan (akademisyenler, insan kaynakları departmanı yöneticileri vb.) sağlanan bilgiler doğrultusunda oluşturulan ve içerisinde işletmelere ve konuya ilişkin bazı nicel verilerin de yer aldığı yarı yapılandırılmış görüşme formundan yararlanılmıştır. Araştırmacılar tarafından hazırlanan söz konusu yarı yapılandııımış görüşme formu kapsamındaki bilgiler, gerekli randevular alındıktan sonra araştırma kapsamında bulunan on adet beş yıldızlı termal otel işletmesinin insan kaynakları departmanı yöneticileri ile yüz yüze görüşülmesi sonucu elde edilmiştir. Bizzat araştırmacılar tarafından yürütülen görüşmelerde termal otel işletmelerindeki insan kaynakları departmanı yöneticilerine ilk olarak; kendilerine (yaş, cinsiyet, eğitim durumu, hizmet süresi vb.), otel işletmesine (oda sayısı, yatak sayısı, personel sayısı, personel eğitim düzeyi vb.) ve oteldeki insan kaynaklarından sorumlu departmana ilişkin genel bilgiler (birimin adı, birimde çalışan personel sayısı, birimdeki personelin eğitim düzeyi vb.) sorulmuştur. Daha sonra kendi içinde gruplandırılarak oluşturulmuş personel bulma, seçme ve personeli işe yerleştirme süreçleri ile ilgili sorulara (personel bulmada en çok yararlanılan iç ve dış kaynaklar, en çok yararlanılan personel seçme yöntemleri, personel deneme süreleri, sendikalaşma bilgilendirmesi, uygulanan ayrımcılık vb.) yer verilmiştir. Son olarak ise Afyonkarahisar'da personel bulma, seçme ve personeli işe yerleştirme süreçlerinde ne gibi zorluklar/sorunlarla karşılaşıldığı sorgulanmış olup elde edilen bilgiler not edilerek raporlaştırılmış, betimsel ve içerik analizi ile araştırmanın amacı doğrultusunda yorumlanarak konuya ilişkin ilgili taraflara öneriler geliştirilmiştir.

\section{Bulgular}

Termal otel işletmelerinde personel bulma, seçme ve personeli işe yerleştirme sürecine yönelik yapılan bu çalışmada elde edilen bulgular; ilk olarak, otel işletmelerine ve otel işletmelerindeki insan kaynakları departmanına yönelik genel bilgiler çerçevesinde sunulmuştur. Daha sonra otel işletmelerindeki personel bulma, seçme ve personeli işe yerleştirme süreçlerine ilişkin bulgulara, ayrı ayrı gruplandırılarak yer verilmiştir. Takibinde ise termal otel işletmelerinin bu süreçler dâhilinde ve Afyonkarahisar genelinde yaşamış oldukları sorunlar yorumlanarak konuyla ilgili öneriler geliştirilmiştir.

\subsection{Termal Otel İşletmelerine ve İnsan Kaynakları Departmanına İlişkin Bulgular}

Afyonkarahisar'da faaliyet gösteren toplam on adet beş yıldızlı termal otel işletmesinde gerçekleştirilen araştırmada; otel işletmelerinin, 246'sı $(\% 13,1)$ termal alanda çalışan personel olmak üzere toplam 1883 personel çalıştırdığı belirlenmiştir. Araştırma kapsamındaki termal otel işletmelerindeki söz konusu personelin eğitim durumlarının da, otel işletmelerinin insan kaynakları departmanı yöneticilerinin beyanlarına göre; her eğitim düzeyinde çalışana sahip olunmakla birlikte ağırlıklı olarak lise mezunu düzeyinde çalışanlara sahip olunduğu saptanmıştır.

Otel işletmelerinin insan kaynakları departmanlarına ilişkin bulgular kapsamında üç otel işletmesinin insan kaynakları departmanında ikişer personelin, yedi otel işletmesinde ise birer personelin bu departmana bağlı olarak çalıştığı belirlenmiş olup; görüşme yapılan insan kaynakları departmanı yöneticilerinin sekizinin kadın, ikisinin erkek olmak üzere ortalama 29,8 yaşlarında olduğu ve yine ortalama olarak 2,5 yıldır işletme bünyesinde aynı pozisyonda çalıştığı sonucuna ulaşılmıştır. Detaylı incelendiğinde, araştırma kapsamındaki tüm otel işletmelerinde insan kaynakları departmanına bağlı çalışan toplam 13 personelin tamamının insan kaynakları yönetimi alanı dışında eğitim aldığı ve bu kapsamda onunun $(\% 76,9)$ lisans mezunu, ikisinin 
$(\% 15,4)$ lise mezunu, birinin $(\% 7,7)$ ön lisans mezunu olduğu belirlenmiştir. Aynı zamanda bu departmandaki 13 personel arasından sadece birinin $(\% 7,7)$ turizm alanında eğitim aldığı (ön lisans düzeyinde) saptanmıştır. Geri kalan personelin en çok işletme olmak üzere ticaret, yönetim bilişim sistemleri, çalışma ekonomisi ve maliye bölümlerinde eğitim aldığı görülmektedir. Bu durumu destekler nitelikteki bir diğer bulgu olarak ise araştırma kapsamındaki beş otel işletmesinin, insan kaynakları departmanına personel alırken insan kaynakları yönetimi alanında eğitim alıp almamasını önemsemedikleri saptanmıştır. Araştırmanın bu kısmında son olarak, görüşülen otel işletmelerinin tamamında insan kaynakları departmanı dahilinde personel bulma, seçme ve personeli işe yerleştirme süreciyle ilgilenen herhangi bir alt birimin bulunmadığı saptanmıştır.

\subsection{Personel Bulma, Seçme ve Personeli İşe Yerleştirme Süreçlerine İlişkin Bulgular}

Araştırmanın bu bölümünde görüşülen insan kaynakları yöneticilerinden elde edilen veriler doğrultusunda, termal otel işletmelerinin; personel bulma, seçme ve personeli işe yerleştirme süreçleri ile ilgili uygulamaları ortaya konulmuştur.

Personel Bulma Süreci: Araştırma kapsamındaki dört otel işletmesi, işletmede yer alan departmanların herhangi bir personel intiyacını insan kaynakları departmanına bildirirken, "sadece insan kaynakları departmanı yöneticisiyle birebir görüşme" yolunu tercih ettiğini; üç otel işletmesi, "sadece personel istek formu" kullanmayı tercih ettiğini; bir otel işletmesi, "hem insan kaynakları departmanı yöneticisiyle birebir görüşmeyi hem de personel istek formu" kullanmayı tercih ettiğini; bir otel işletmesi, "insan kaynakları departmanı yöneticisiyle birebir görüşmeyi tercih ederken aynı zamanda mail aracılığıyla bildirmeyi" de tercih ettiğini, geri kalan son otel işletmesi de "personel istek formu" kullanımının yanında "mail" aracılığıyla da bildirmeyi tercih ettiğini belirtmiştir.

Otel işletmelerinden ikisinin, gelecekteki personel intiyacını belirlerken, sadece "yönetici tahminlerine"; birinin, sadece "istatistiksel tekniklere"; yine birinin, sadece "iş yükü analizlerine"; üçünün "hem istatistiksel tekniklere hem de yönetici tahminlerine"; bir otel işletmesinin de "istatistiksel tekniklerle birlikte iş yükü analizlerine" başvurduğu belirlenmiştir. Geri kalan iki otel işletmesinin ise gelecekteki personel ihtiyacını belirlemek için herhangi bir yöntem kullanmayı tercih etmediği gözlemlenmiştir.

Otel işletmelerinin tamamında, zorunlu tutulan turizm alanında mesleki eğitim almış personel çalıştırma oranının kontrolünün yapıldığı belirlenmiştir. Aynı zamanda üç otel işletmesinin, gerekli olması durumunda işe alabileceği turizm konusunda bilinçli kişileri sayısal olarak bilmediği ortaya çıkmıştır.

Araştırmada ayrıca yönetici düzeyinde ve yönetici düzeyinde olmayan personeli bulma sürecinde termal otel işletmelerinin tercih ettiği kaynakların detaylı incelemesi yapılmıştır. Bu doğrultuda ilk olarak Tablo 2'de yönetici düzeyinde personel bulmada kullanılan kaynaklara ilişkin verilere yer verilmiştir. Tablo 2'de görüldüğü üzere, yönetici düzeyinde personel bulmada tercih edilen iç kaynaklar tercih edilme durumuna göre sıralandığında, birinci sırada en çok tercih edilen iç kaynağın, sekiz kez birinci sırada tercih edilen "terf?" olduğu görülmektedir. Toplam tercih edilme sayısı bakımından sıralandığında da toplam on kez tercih edilen "terfiinin", en çok tercih edilen iç kaynak olduğu dikkat çekmektedir. Yine aynı tablo doğrultusunda, yönetici düzeyinde personel bulmada tercih edilen dış kaynaklar tercih edilme durumuna göre sıralandığında, birinci sırada en çok tercih edilen dış kaynağın, beş kez tercih edilen "ilan" olduğu 
görülmektedir. Dış kaynaklar toplam tercih edilme sayısı bakımından sıralandığında ise toplam sekiz kez tercih edilen "ilanın", en çok tercih edilen dış kaynak olduğu dikkat çekmektedir.

Tablo 2: Yönetici Düzeyinde Personel Bulmada Kullanılan Kaynaklar

\begin{tabular}{|c|c|c|c|c|c|c|c|c|c|c|c|c|c|c|}
\hline \multicolumn{7}{|c|}{ İç Kaynaklar } & \multicolumn{8}{|c|}{ Dış Kaynaklar } \\
\hline 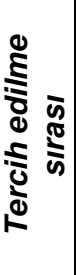 & $\stackrel{\frac{E}{0}}{\bullet}$ & 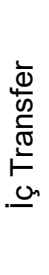 & 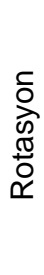 & 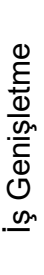 & 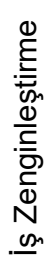 & 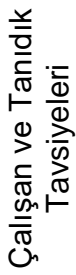 & 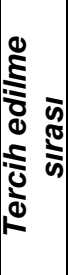 & $\begin{array}{l}\frac{\bar{\sigma}}{\frac{\pi}{c}} \\
\stackrel{\frac{\pi}{\sigma}}{=}\end{array}$ & 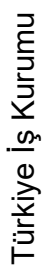 & 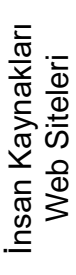 & 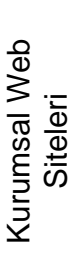 & 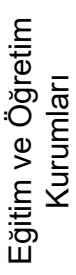 & 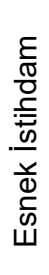 & 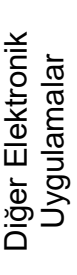 \\
\hline 1. & 8 & 1 & - & 1 & 3 & - & 1. & 5 & 1 & 1 & - & 2 & - & 1 \\
\hline 2. & 1 & 4 & 2 & - & - & - & 2. & 1 & 2 & 5 & - & 1 & - & - \\
\hline 3. & 1 & 1 & 3 & & 1 & 3 & 3. & 1 & 1 & & 3 & - & - & - \\
\hline 4. & - & - & - & 1 & - & 1 & 4. & 1 & & 1 & 1 & - & - & - \\
\hline 5. & - & 1 & - & - & - & & 5. & - & 1 & - & - & 1 & - & - \\
\hline 6. & - & - & - & - & - & 1 & 6. & - & - & - & - & - & 1 & - \\
\hline$\Sigma$ & 10 & 7 & 5 & 2 & 4 & 5 & $\Sigma$ & 8 & 5 & 7 & 4 & 4 & 1 & 1 \\
\hline
\end{tabular}

Yönetici düzeyinde personel bulmada kullanılan kaynaklara ait verilerin incelenmesinin ardından kaynakların tercih edilme sıklığının yönetici düzeyinde olmayan personeli bulma süreci kapsamında incelenmesi, Tablo 3 kapsamında ele alınmıştır.

Tablo 3: Yönetici Düzeyinde Olmayan Personeli Bulmada Kullanılan Kaynaklar

\begin{tabular}{|c|c|c|c|c|c|c|c|c|c|c|c|c|c|c|c|}
\hline \multicolumn{8}{|c|}{ İç Kaynaklar } & \multicolumn{8}{|c|}{ Dış Kaynaklar } \\
\hline 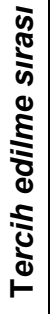 & $\stackrel{\bar{E}}{\stackrel{E}{\sigma}}$ & 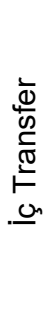 & 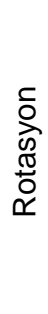 & 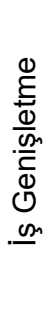 & 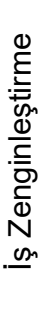 & 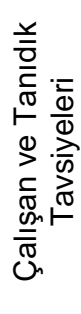 & 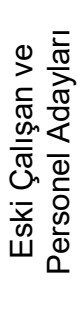 & 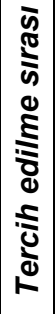 & $\begin{array}{l}\frac{\bar{\sigma}}{\frac{\sigma}{c}} \\
. \frac{\sigma}{=}\end{array}$ & 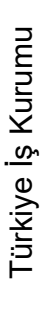 & 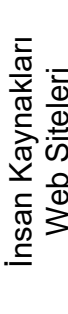 & 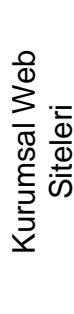 & 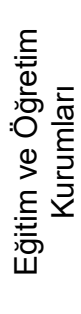 & 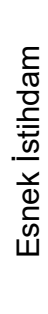 & 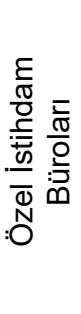 \\
\hline 1. & 4 & 2 & 1 & 1 & & 2 & - & 1. & 4 & 4 & - & - & 2 & - & - \\
\hline 2. & 3 & 2 & 2 & 1 & 1 & 1 & - & 2. & 2 & 3 & 4 & - & - & - & - \\
\hline 3. & 1 & 1 & 1 & 1 & 1 & 2 & 1 & 3. & 1 & 1 & 2 & 2 & 1 & - & - \\
\hline 4. & - & - & 1 & 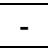 & - & 2 & - & 4. & 1 & 1 & - & 1 & 2 & 1 & \\
\hline 5. & - & - & - & - & - & 1 & - & 5. & - & - & - & - & 2 & - & 1 \\
\hline$\Sigma$ & 8 & 5 & 5 & 3 & 2 & 8 & 1 & $\Sigma$ & 8 & 9 & 6 & 3 & 7 & 1 & 1 \\
\hline
\end{tabular}

Tablo 3'de görüldüğü üzere, yönetici düzeyinde olmayan personel bulmada tercih edilen iç kaynaklar tercih edilme durumuna göre sıralandığında, birinci sırada en çok tercih edilen iç kaynağın, dört kez birinci sırada tercih edilen "terf" olduğu görülmektedir. Toplam tercih edilme sayısı bakımından sıralandığında da toplam sekizer kez tercih edilen "terfi" ve "tavsiyelerin", en çok tercih edilen iç kaynaklar olduğu dikkat çekmektedir. Yine aynı tablo doğrultusunda, yönetici düzeyinde olmayan personeli bulmada tercih edilen dış kaynaklar tercih edilme durumuna göre sıralandığında, birinci sırada en çok tercih edilen dış kaynakların, dörder kez tercih edilen "ilan" ve "Türkiye İş Kurumu" olduğu görülmektedir. Dış kaynaklar toplam tercih edilme sayısı bakımından sıralandığında ise toplam dokuz kez tercih edilen "Türkiye iş Kurumu'nun", en çok tercih edilen diş kaynak olduğu dikkat çekmektedir. 
Araştırmada dış kaynakların tercih edilme sıklığına ilişkin bulguların dışında termal otel işletmelerinin personel bulma sürecinde dış kaynak kullanmayı tercih etmesine yönelik nedenler sorgulanmış, bu nedenler ve bu nedenlerin tercih edilme sıklığı Tablo 4'de belirtilmiştir. Tablo 4 kapsamında otel işletmelerine personel bulmada dış kaynak kullanmayı tercih ettiren nedenler tercih edilme durumuna göre sıralandığında, altı kez birinci sırada tercih edilen "daha yetenekli personel adaylarının bulunmasına olanak tanıması", ilk sırada gelmektedir. Tablodaki belirtilen nedenler otel işletmelerince tercih edilme sırası dikkate alınmadan sıralandığında da yine "daha yetenekli personel adaylarının bulunmasına olanak tanıması", toplam dokuz kez tercih edilerek en çok tercih edilen neden olarak dikkat çekmektedir.

Tablo 4: İşletmelere Dış Kaynak Kullanmayı Tercih Ettiren Nedenler

\begin{tabular}{|c|c|c|c|c|c|}
\hline 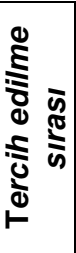 & $\begin{array}{c}\text { Daha yetenekli } \\
\text { personel } \\
\text { adaylarının } \\
\text { bulunmasına } \\
\text { olanak } \\
\text { tanıması }\end{array}$ & $\begin{array}{c}\text { İşletmenin } \\
\text { sahip olduğu iç } \\
\text { kaynakların } \\
\text { yetersiz olması }\end{array}$ & $\begin{array}{c}\text { İşletmeye yeni } \\
\text { fikir ve } \\
\text { görüşlerin } \\
\text { girmesine } \\
\text { olanak } \\
\text { tanıması }\end{array}$ & $\begin{array}{c}\text { Çalışan } \\
\text { personel } \\
\text { arasında } \\
\text { olumlu rekabet } \\
\text { ortamını } \\
\text { yaratmasını } \\
\text { sağlaması }\end{array}$ & $\begin{array}{c}\text { Ucuz } \\
\text { işgücünden } \\
\text { yararlanılması }\end{array}$ \\
\hline 1. & 6 & 2 & 1 & 1 & - \\
\hline 2. & 2 & 1 & 2 & 2 & 1 \\
\hline 3. & 1 & 3 & - & - & - \\
\hline 4. & - & - & 1 & - & 1 \\
\hline$\Sigma$ & 9 & 6 & 4 & 3 & 2 \\
\hline
\end{tabular}

Personel Seçme Süreci: Toplam on termal otel işletmesinin tamamının, başvuran personel adayları ile bir ön görüşme gerçekleştirdiği gözlemlenmiştir. Yedi otel işletmesi, bu ön görüşmenin sadece insan kaynakları departmanı yöneticisi tarafından gerçekleştirildiğini; üç otel işletmesi ise insan kaynakları departmanı yöneticisi ile görüşüldükten sonra ilgili departman yöneticisi ile de bir ön görüşme yapıldığını belirtmiştir.

Termal otel işletmelerinin personel seçme sürecinde kullandığı yöntemler ve termal otel işletmeleri tarafından tercih edilme sıklıkları aşağıda yer alan Tablo 5 'te belirtilmiştir.

Tablo 5: Personel Seçmede Kullanılan Yöntemler

\begin{tabular}{|c|c|c|c|c|c|c|c|c|c|c|c|c|c|}
\hline \multicolumn{7}{|c|}{$\begin{array}{c}\text { Yönetici Düzeyinde } \\
\text { Personel }\end{array}$} & \multicolumn{7}{|c|}{ Yönetici Düzeyinde Olmayan Personel } \\
\hline 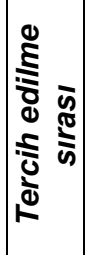 & 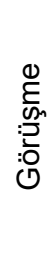 & 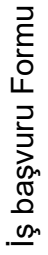 & 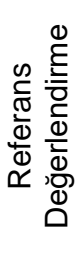 & $\begin{array}{l}\frac{\vec{\pi}}{\omega} \\
\frac{\stackrel{5}{n}}{4}\end{array}$ & 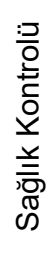 & 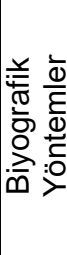 & 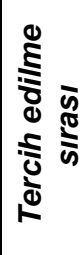 & 華 & 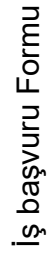 & 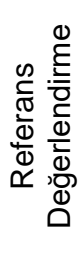 & $\begin{array}{l}\overrightarrow{\mathbb{d}} \\
\stackrel{\vec{\omega}}{\omega}\end{array}$ & 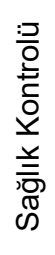 & 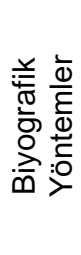 \\
\hline 1. & 3 & 6 & 1 & - & - & - & 1. & 2 & 8 & - & - & - & - \\
\hline 2. & 7 & 2 & - & - & - & - & 2. & 8 & 1 & - & - & - & - \\
\hline 3. & - & 1 & 8 & & & & 3. & - & - & 9 & - & - & - \\
\hline 4. & - & - & - & 1 & 4 & - & 4. & - & - & 1 & 1 & 4 & - \\
\hline 5. & - & - & - & - & - & 1 & 5. & - & - & - & - & - & 1 \\
\hline$\Sigma$ & 10 & 9 & 9 & 1 & 4 & 1 & $\Sigma$ & 10 & 9 & 10 & 1 & 4 & 1 \\
\hline
\end{tabular}


Tablo 5 kapsamında yönetici düzeyinde personeli seçmede tercih edilen yöntemler tercih edilme durumuna göre sıralandığında, birinci sırada en çok tercih edilen yöntemin, altı kez tercih edilen "iş başvuru formu" olduğu görülmektedir. Yönetici düzeyinde personeli seçmede kullanılan yöntemler toplam tercih edilme sayısı bakımından sıralandığında ise toplam on kez tercih edilen "görüşmenin", en çok tercih edilen yöntem olduğu dikkat çekmektedir. Yine aynı tablo doğrultusunda yönetici düzeyinde olmayan personeli seçmede tercih edilen yöntemler tercih edilme durumuna göre sıralandığında, birinci sırada en çok tercih edilen yöntemin, sekiz kez tercih edilen "iş başvuru formu" olduğu görülmektedir. Yönetici düzeyinde olmayan personeli seçmede kullanılan yöntemler toplam tercih edilme sayısı bakımından sıralandığında ise onar kez tercih edilen "görüşme" ve "referans değerlendirmenin", en çok tercih edilen yöntemler olduğu dikkat çekmektedir.

Personel seçme sürecine yönelik başka bir soru kapsamında yedi otel işletmesi, "personel adayları ile gerçekleştirilen görüşmelerin, ilk önce insan kaynakları departmanı yöneticisi ile yapıldığını; insan kaynakları departmanı yöneticisi ile görüşüldükten sonra ilgili departman yöneticisi ile görüşüldüğünü ve en son ise genel müdür tarafından bir görüşme gerçekleştirildiğini" belirtmişlerdir. Bunun dışında iki otel işletmesinde, "görüşmelerin ilk olarak insan kaynakları departmanı yöneticisi daha sonra ilgili departman yöneticisi tarafından gerçekleştirildiği"; bir otel işletmesinde ise "sadece ilgili departman yöneticisi tarafından bir görüşme gerçekleştirildiği" saptanmıştır.

Otel işletmelerinin üçünde, insan kaynakları departmanı yöneticilerinin veya işe alınacak personelle ilgili departman yöneticilerinin mevcut eğitim durumunun; otel işletmesine başvuran bir personel adayının işe seçilmesini olumsuz yönde etkilediğini saptanmıştır. Yine otel işletmelerinin üçü, insan kaynakları departmanı yöneticilerinin veya işe alınacak personelle ilgili departman yöneticilerinin mezun olduğu eğitim kurumunun, otel işletmesine başvuran bir personel adayının mezun olduğu eğitim kurumuyla aynı olmasının; personel adayının işe seçilmesini olumlu yönden etkilediğini belirtmiştir.

İki otel işletmesi, başvuran bir personel adayının siyasi görüşünün, işe seçilip seçilmemesini etkilediğini; iki otel işletmesi de başvuran bir personel adayının memleketinin, işe seçilip seçilmemesi etkilediğini öne sürmüştür.

Dört otel işletmesi tarafından, bir personel adayının düşük ücret talep etmesinin işe seçilmesini kolaylaştırdığı belirtilmiştir. Ancak bununla birlikte altı otel işletmesinde personel adaylarının lojman talebinde bulunması veya lojman kullanmasının gerekli olması durumunun ise personel adaylarının işe seçilmelerini olumsuz yönde etkilediği belirlenmiştir.

Toplam on otel işletmesinin tamamında, kullanılan iş başvuru formunun otel işletmesinde yer alan tüm departmanlar için ortak bir form niteliğinde olduğu belirlenmiş olup; dört otel işletmesindeki insan kaynakları departmanı yöneticilerinin, bu iş başvuru formunun hazırlanma ve düzenlenme aşamasında yer almadığı tespit edilmiştir. Aynı zamanda yedi otel işletmesi, iş başvuru formlarında yer alan bilgilerin herhangi bir ayrımcılık unsuru oluşturup oluşturmadığına yönelik herhangi bir kontrolün yapılmadığını belirtmiştir.

Dikkat çeken bir diğer bulgu dahilinde, otel işletmelerinin tamamında personel seçme aşamasında bir personel adayının deneyim sahibi olmasının mesleki eğitim derecesine göre daha önemli bir kriter olduğu saptanmıştır. Bunun yanında on otel 
işletmesinin de personel seçerken; personel adayında termal otel deneyimine daha çok önem verdiği ve daha önce termal otellerde çalışan personel adaylarına öncelik tanıdığı belirlenmiş olmakla birlikte termal alanda çalışacak sağlık personelini seçerken turizm alanındaki bilgi ve becerisinin ise beş otel işletmesi tarafından ölçülmediği saptanmıştır.

Personeli İşe Yerleştirme Süreci: Araştırma kapsamındaki otel işletmelerinin tamamı, çalışma şartlarının işe yerleştirme sürecinde personel adaylarına doğru ve eksiksiz bir şekilde anlatıldığını; çalışma şartlarına ayak uyduramayacak personelin işe yerleştirilmesinin önüne geçildiğini ve işe yerleştirilen personel adayının mevcut personel ile kısa sürede bütünleşmesinin sağlandığını belirtmiştir. Bu doğrultuda aynı zamanda otel işletmelerinin tamamında, işe yerleştirilen adaya bir oryantasyon eğitimi uygulandığı saptanmıştır. Ancak bunların yanında bir otel işletmesi tarafından işe yerleştirilen sağlık personelinin, işe yerleştirme sürecinde turizm alanında bilgi ve beceri kazanmasının sağlanmadığı belirlenmiştir. Yine otel işletmelerinin sadece biri, personel adayını herhangi bir deneme sürecine tabi tutmadan işe yerleştirmekteyken; kalan dokuzunun, personeline iki aylık bir deneme süreci uyguladığı tespit edilmiştir.

Araştırma kapsamındaki otel işletmelerinden altısının, lojman imkânına sahip olduğu saptanmış olmakla birlikte; bu altı otel işletmesinden ikisinin, işe yerleştirilen personel ile çalışan personelin lojman kullanımında eşit standart ve şartların uygulanmasına dikkat etmediği ortaya konmuştur. Bununla birlikte otel işletmelerinden birinin, birtakım ayrımcılıklar ile işe yerleştirilen bir adayın uygun nitelikte olmadığı halde, yine de işine devam ettirebileceğini belirttiği de dikkat çekici başka bir bulgudur.

Bunun dışında otel işletmelerinden hiçbirinin, personeli işe yerleştirme sürecinde sendikalaşma hakkında personel adaylarına herhangi bir bilgilendirme yapmadığı tespit edilmiştir.

Personel Bulma, Seçme ve Personeli İşe Yerleştirme Süreçlerinde Termal Otel İşletmelerinde ve Afyonkarahisar Genelinde Yaşanan Sorunlara İlişkin Bulgular

Araştırma kapsamındaki termal otel işletmelerindeki görüşülen insan kaynakları departmanı yöneticileri, Afyonkarahisar'da nitelikli ve eğitimli personel bulmada sorunlar yaşandığını belirtmiştir. Bu sorunları aşağıdaki gibi açıklamak mümkündür:

- İlk olarak, nitelikli ve eğitimli personel bulma konusunda; turizm eğitimine ve bilincine sahip olmayan, yabancı dil bilmeyen personel ve personel adaylarının Afyonkarahisar'da oldukça fazla olmasının işletmelerin hizmet kalitesini de olumsuz yönden etkilediği ancak işletme yöneticilerinin bu durumu düzeltecek bir seçenek şanslarının olmadığı ifade edilmiştir.

- Başka bir sorun olarak ise personel adaylarının işletmelerden beklentilerinin fazla olması sonucunda işletmelerde sunulan iş ve ücretleri beğenmedikleri, özellikle turizm eğitimi almış kişilerin bu yüzden başvurmayı bile düşünmedikleri belirtilmiştir.

- Diğer yandan, görüşülen insan kaynakları departmanı yöneticileri, personel seçme sürecinde personel adaylarının görüşmelere gelirken görünüşlerine önem vermediklerini belirterek adayların işleri ve işletmeleri pek fazla önemsemediklerini öne sürmüşlerdir.

- Bunun yanında bazı işletmeler, personeline lojman imkânı sunamamalarının personel adaylarını işletmelerine çekme konusunda kendilerine bir dezavantaj yarattığını ifade etmiştir.

- Yöneticiler tarafından değinilen başka bir sorun, işletmelerde çalışan personelin işletmeye sadakat ve aidiyet duygularının olmamasından dolayı birtakım nedenler (yeni açılan diğer otel işletmelerinin daha yüksek ücret teklif etmesi, yaşanan örgüt içi çatışmalar, personel arası rekabet, lojman imkânında eşit şartlar sunulmaması) 
devreye girince çok rahat ve ani bir şekilde işten ayrılmaları olmuştur. Bu bağlamda yöneticiler, otel işletmelerindeki personel devir hızlarının yüksek olduğunu belirtmiştir.

- Başka bir sorun olarak, personel devir hızını yükseltmesine etki eden Afyonkarahisar'daki otel işletmelerindeki mevcut personelle yöneticiler arasındaki samimiyetin arttıkça ast/üst ilişkilerinde aksaklıklara neden olunması, personelin işini layığıyla yapmamaya başlaması gibi nedenler öne sürülmüştür. Bu yüzden otel işletmelerinin bazılarında özellikle yiyecek-içecek departmanında birçok personel ile yolların ayrıldığı ifade edilmiştir.

- Son olarak bilinmektedir ki, işten ayrılmaların personel bulma, seçme ve personeli işe yerleştirme süreçlerinin tekrar yaşanması anlamına geldiği ortada bir gerçektir. Boşalan kadroları doldurmak için ise tanıdık yönlendirmelerinin ve adaylara referans olan kişilerin sayısının çok fazla olmasının, personel seçme sürecinde yöneticileri zor durumda bıraktığı belirtilmiştir. Referans olunan personel adaylarının da işe alındıktan sonra işletmenin beklediğini verecek düzeyde olamamasının, işletmeleri zor duruma sokan diğer bir sorun olduğu aktarılmıştır.

\section{Tartışma, Sonuç ve Öneriler}

Günümüzdeki bilgi ve teknolojideki gelişmeler ile birlikte turizm işletmeleri arasında yaşanan rekabet ortamı, işletmelerin birbirlerine karşı üstünlük kurmasını sağlayan insan faktörünün önemini ve insan faktörüne olan ihtiyacı arttırırken, bu ihtiyacın karşılanmasında başvurulan uygulamaları daha önemli kılmıştır. Personel bulma, seçme ve personeli işe yerleştirme süreçlerinde başvurulan uygulamalar; işletmenin personel devir hızıyla, personelin işletmenin intiyaç duyduğu niteliklere ve işletmenin hedeflerine olan uygunluğuyla, kısaca işletmenin sürdürülebilirliği ve verimliliği gibi işletmenin başarısında önemli rol oynayan unsurlarla yakından ilgilidir (Akova ve diğ., 2007: 292). Bu bağlamda araştırmada, kendisine özgü birtakım özellikler taşıyan termal otel işletmelerinin, bu süreçler kapsamında başvurdukları uygulamalar ve karşılaştıkları sorunlar incelenmiştir.

Araştırmanın sonucunda saptanan termal otel işletmelerindeki personel bulma süreci uygulamaları, uygulamalardaki birtakım sorunlar ve bu sorunlara yönelik çözüm önerileri aşağıda belirtilmiştir:

- Termal otel işletmelerinde bulunan personel adaylarının işletmelerdeki ücret ve işleri beğenmemesi ve çok kolay iş değiştirmeleri, Temizkan'ın (2015: 281-282) üzerinde durduğu işgücü piyasasındaki yaşanan değişimlerle ilgilidir. Bu noktada termal otel işletmeleri, ücret politikasını rakip termal otel işletmeleri ile kıyaslayarak sürekli kontrol etmeli; sektördeki ücret düzeyleri düşük olduğu için aradaki fark çok az dahi olsa gidermelidir. İşin ve işletmenin beğenilmesi ise personele sunulacak esnek çalışma saatler, promosyonlar, ödüllendirmeler, teşvikler, sosyal olanaklar gibi çeşitli faaliyetler ve bu faaliyetler hakkındaki detaylı bilginin verilmesi ile sağlanmalıdır.

- Afyonkarahisar'da otel işletmeleri için nitelikli ve eğitimli personel bulmanın zorluğu, Keskin'in (1998: 49) belirttiği gibi genel anlamda otel işletmeleri için personel bulma sürecindeki başarısızlığın temelini oluşturan etmen olarak dikkat çekmektedir. Bu sorun, turizm sektörü genelinde görülmekle birlikte Afyonkarahisar özelinde ayrı bir değerlendirmeyi gerektirmektedir. Bu noktada termal otel işletmeleri, gerektiğinde özellikle yönetici düzeyinde, yüksek ücret ve zengin olanaklar ile şehir dışında ikamet eden personel adaylarını işletmelerine çekebilmelidir. Bunun yanı sıra turizm eğitimi almış ancak tecrübesiz personel adaylarını da işe alarak gelişimlerini sağlayıp, işletmelerinin hizmet kalitesini yüksek standartlara taşımalı ve rekabet 
avantajı elde edilmesini sağlamalıdır. Ayrıca gelişimine katkı sağlanan personel, işletmeden ayrılıp başka bir işletmeye geçse dahi, durum Afyonkarahisar genelinde düşünüldüğünde, şehirdeki tüm termal otel işletmeleri için özellikle yönetici düzeyinde intiyaç duyulan nitelikli ve eğitimli bir potansiyel personel adayı olarak sektörde yerini alacaktır. Bunun dışında, yabancı dil bilmeyen personel ve personel adaylarının yüksek sayıda olması nedeniyle, bu sorunun işletme içi veya dışında çeşitli eğitim programlarıyla çözümü üzerine yoğunlaşılmalıdır.

- İhtiyaç olan personelin belirlenmesinde yoğunlukla (\%50) yönetici tahminlerine başvuran termal otel işletmelerinin özetle amatör tutumlar sergilemesi, Çabuk (2005: 115-116) tarafından yapılan araştırmanın sonuçlarıyla aynı doğrultudadır. Bununla birlikte termal otel işletmelerinin \%20'sinin gelecekteki intiyacı olan personeli belirlemek amacıyla herhangi bir yöntem kullanmayı tercih etmediği dikkat çekmektedir. Ayrıca termal otel işletmelerindeki departmanların ağırlıkla (\%60) ihtiyaç duydukları personeli insan kaynakları departmanına bildirmede sözlü iletişimi tercih etmesi; diğer departmanlar ile insan kaynakları departmanı arasında sistematik bir ilişki-iletişim düzeninin olmadığını ortaya koyan Erdem'in (2002: 161) araştırmasındaki sonucu destekler niteliktedir. Bu noktada termal otel işletmelerinde, insan kaynakları yönetimine tam olarak önem verilmediği ve insan kaynakları departmanının gerekli konularda tam olarak yetkilendirilmediği görülmektedir. Ayrıca insan kaynakları yönetimi alanında eğitim almamış insan kaynakları departmanı yöneticilerinin de gerekli yetkilendirme ve olanakların verilmesi halinde dahi ne derece başarılı olacakları da belirsizdir. Bu kapsamda bahsi geçen termal otel işletmeleri, insan kaynakları departmanlarında görevli personel niteliğini ve sayısını artırarak ilgili konularda sistematik bir düzen dâhilinde daha fazla yetkilendirme ile daha profesyonel uygulamalara başvurmalıdır.

- Termal otel işletmelerinde terfi ve ilanlara yoğun olarak personel bulma kaynağı olarak başvurulduğu saptanmıştır. Bu sonuca benzer sonucu Akbaba ve Günlü (2011: 221) otel işletmelerinde süregelmiş personel bulma yöntemlerinin yoğun bir şekilde uygulandığını belirterek ortaya koymuştur. Ancak, literatürde; Türkiye İş Kurumu, eğitim kurumları ve internet gibi personel bulma kaynaklarının inmal edildiğini vurgulayan birçok çalışmanın (Akbaba ve Günlü, 2011: 219; Bilgiçli, 2010: 95; Temizkan, 2010: 163) aksine, termal otel işletmelerinin personel bulmada Türkiye İş Kurumu, eğitim kurumları ve internet gibi kaynaklara azımsanamayacak derecede başvurduğu belirlenmiştir. Ancak bu farklılık bağlamında son yıllarda Türkiye İş Kurumu'nun işletmelere sağladığı istihdamı kolaylaştırıcı ve teşvik eden uygulamalarının etkisi göz ardı edilmemelidir.

Araştırmanın sonucunda saptanan termal otel işletmelerindeki personel seçme sürecine ilişkin uygulamaları, uygulamalardaki birtakım sorunları ve bu sorunlara yönelik çözüm önerilerini aşağıda belirtildiği gibi ele almak mümkündür:

- Termal otel işletmelerinde azımsanamayacak oranda (\%30) insan kaynakları departmanı yöneticilerinin veya işe alınacak personelle ilgili departman yöneticilerinin mevcut eğitim durumlarının; otel işletmesine başvuran bir personel adayının işe seçilmesini olumsuz yönde etkilediğini saptanmıştır. Yöneticilerin kendi eğitim düzeyinden daha yüksek eğitim düzeyine sahip personel adayını gelecekte kendilerine rakip olabileceklerini düşünmeleri sebebiyle bu nitelikteki personeli işe seçmeme eğiliminde oldukları görülmektedir. Bu konuyla ilgili, Örücü (2002: 130) de araştırmasında bu durumun varlığına işaret etmiştir. Bu sorun, söz konusu otel işletmelerindeki insan kaynakları departmanlarından ziyade diğer departman yöneticilerinden kaynaklanmaktadır. Bu durumda söz konusu departman yöneticilerinin kariyerleri ile ilgili endişeleri giderilmeli ve bu durumu önleyici tedbirler 
(insan kaynakları yönetimi eğitimi, kariyer planlaması, psikolojik destek vb.) uygulanmalıdır.

- Termal otel işletmelerinin tamamında, insan kaynakları departmanı yöneticilerinin, personel seçerken deneyim faktörüne eğitimden daha fazla önem verdiklerini belirtmesi, bu konuyla ilgili araştırma sonuçlarıyla (Chan ve Kuok, 2011: 429; Şimşek ve diğ., 2014: 163) aynı doğrultudadır ve önemli sorun grupları arasındadır. Bu durumda termal otel işletmelerinde yapılması gereken bu dengenin sağlanması ve korunması olmalıdır.

- Süregelmiş personel seçme yöntemlerinin (görüşme, iş başvuru formu, referans değerlendirme) termal otel işletmelerinde halen yoğun bir şekilde uygulanması, literatürdeki bazı çalışmaları (Akoğlan, 1998: 27; Akbaba ve Günlü, 2011: 221; Chan ve Kuok, 2011: 429) destekler niteliktedir. Termal otel işletmeleri müşteri profilinin genellikle daha çok anlayış, hoşgörü, sabır ve ilgi isteyen yaşlılar ve hastalardan oluşması sebebiyle, işe seçerken adayların bu tür özelliklerini tespit etmeye yönelik testlerin kullanılması yerinde olacaktır.

- Termal otel işletmelerinin \%70'inde insan kaynakları departmanı yöneticileri iş başvuru formlarında herhangi bir ayrımcılık unsuru içeren bilginin kontrolünün yapılmadığını belirtmiştir. Bu sonuç ise personel seçme aşamasında ve özellikle iş başvuru formlarında gerekli olmayan, ayrımcılığa tabi tutulabilecek bilgilerin istendiğini öne süren araştırmaları (Yeşiltaş ve diğ., 2010: 192-193; Temizkan, 2010: 163-167) desteklemektedir. Bu durumun çözümünde insan kaynakları departmanı yöneticilerine, ayrımcılığa yönelik eğitim ve bilgiler verilmeli; iş başvuru formlarının hazırlanma aşamasında ayrımcılık unsurlarının kontrolünü yapabilecek düzeye gelmeleri sağlanmalıdır.

- Termal otel işletmelerinin \%20'sinde siyasi ayrımcılık, \%20'sinde hemşehricilik yapıldığı sonucu, bu konuyu işaret eden diğer çalışmaların (Yeşiltaş ve diğ., 2012: 108-109; Demir, 2011: 781) sonuçlarıyla da örtüşmektedir. Bu noktada ayrımcılığa yönelik eğitilen yöneticiler; gerek ön görüşme ve görüşme gerekse de iş başvuru formlarında, bu bilgileri öğrenmeye yönelik sorulara yer vermemelidir.

- Termal otel işletmelerinin \%40'ının düşük ücret talep eden personel adaylarının seçilme konusunda daha avantajlı olduğunu belirtmeleri, termal otel işletmelerinin kaliteli personelden ziyade ucuz işgücünden yararlanmayı tercih ettiği şeklinde yorumlanmaktadır. Termal işletmelerinde çalışan personelin diğer işletmelerde çalışanlara göre daha fazla nitelikler gerektirmesi (sağlık bilgisi, daha fazla sabır, hoşgörü ve ilgi vb.) ve daha kalifiye personele intiyaç duyulması sebebiyle, talep edilen ücretten ziyade personelin sahip olduğu eğitim, deneyim ve kişisel özellikler ön planda tutulmalıdır.

- Termal otel işletmelerinin \%50'sinde sağlık personeli adaylarının turizm bilgi ve becerisinin ölçülmemesi, diğer otel personeli ile sağlık personeli arasında bir bütünlük olmadığını ortaya koyan verilerdendir. Bu konuda birlikteliği sağlayabilmek adına, sağlık personeline turizm sektörü ve bir hizmet işletmesi olan termal otel işletmesinin özellikleri öğretilerek, farklı departmanlarda çalışan diğer otel çalışanlarına da acil durumlarda sağlık sorunu yaşayan müşterilere müdahale edebilme ve gerekli sağlık birimlerine yönlendirebilme yeteneği kazandırılmalıdır.

- Termal otel işletmelerinin \%60'ında personel adayının lojman talebinde bulunmasının işe seçilmelerini olumsuz yönde etkilediği belirlenmiştir. İşletmeler için maddi açıdan külfet oluşturan lojman talebinde bulunan aday personel ile lojman talebinde bulunmayan diğer adaylar arasında işe seçme aşamasında lojman imkânının sağlanması bir seçme kriteri olarak kullanıımamalıdır.

Araştırmanın sonucunda saptanan termal otel işletmelerindeki personeli işe yerleştirme sürecine ilişkin uygulamalar, bu uygulamalardaki birtakım sorunlar ve sorunlara getirilen çözüm önerileri ise aşağıda belirtilmiştir: 
- Termal otel işletmelerinin \%10'unda işe uygun olmayan personelin birtakım nedenlerden dolayı (pozitif ayrımcılık, hemşehricilik vb.) işe yerleştirilmesine çalışılmasının önüne geçilemediği saptanmıştır. Bu duruma kısmen referans olan kişilerin neden olduğu öne sürülmüştür. Bu bulgu literatürde ayrımcılık konularını ele alan araştırmaları (Yeşiltaş ve diğ., 2012: 108-109; Demir, 2011:781) destekler niteliktedir. Bu durumda otel işletmeleri, personel işe alımının son aşaması olan bu süreç dâhilinde birtakım ölçüt ve kurallar (kişisel inisiyatif kullanılmasının önlenmesi vb.) koymalı ve geliştirmelidir. Bir başka deyişle, otel işletmeleri tarafından ayrımcılık, kayırmacılık, hemşehricilik gibi uygulamaların önüne geçen bir işe yerleştirme politikası belirlenmelidir.

- İşletmelerde aynı görevdeki personel arasında, personel lojmanlarında ağırlama şartlarında oluşabilecek farklııklara Çavdar ve Çavdar (2010: 91) tarafından dikkat çekilmiştir. Bu durum termal otel işletmeleri kapsamında incelendiğinde altı otel işletmesinin lojman imkânı sunduğu belirlenmiştir. Ancak bu altı otel işletmesinin üçte birinin personele eşit şartlar sunamadığı saptanmıştır. Genelde üst düzey yöneticilere bu imkânın sağlandığı ve bunun da otel içindeki bazı bölümlerin/odaların ayrılması şeklinde gerçekleştirildiği belirlenmiştir. Bu durum ise şehir dışından gelen/gelme intimali bulunan nitelikli personelin işletmede çalışmasında bir engel teşkil edecek faktörler arasında değerlendirilebilmektedir. Personele eşit haklar sunan bir lojman tahsis politikasının benimsenmesi için işletme tarafından yetersiz ise üstyapı imkânı sağlanmalı ve lojman olanaklarında iyileştirmeye gidilmeli; neticesinde de hem personel hem de personel adaylarına bu konuda eşitliğin ön planda olduğu vurgulanmalıdır.

- Personeli işe yerleştirme sürecinde termal otel işletmelerinin hiçbirinin, personel adaylarına sendikalaşma hakkında herhangi bir bilgilendirme yapmadığı belirlenmiştir. Bu durum ise turizm literatüründe yer alan sendikalaşma eksikliğinden bahseden çalışmalarla (Tekin ve Tüfekçi, 2015: 193-195) ilişkilendirilebilir. Özellikle otel işletmelerinde terfi, eğitim, kariyer planlaması gibi insan kaynakları yönetimi uygulamalarının varlığı nedeniyle (Yeşiltaş, 2015: 491) genellikle genç ve sendikalaşma konusunda bilgisiz personelin, bu uygulamalar kapsamında olumsuz bir bakış açısına maruz kalmaması amacıyla sendikalaşmadığı düşünüldüğünde, işe yerleştirme sürecinde termal otel işletmeleri, aday personelini sendikalaşma hakkında destekleyici bir tavırla bilgilendirmelidir.

Genel olarak değerlendirildiğinde Afyonkarahisar'daki termal otel işletmelerinin nitelikli personel istihdam etmede sıkıntılar yaşadığını ortaya koyan bu araştırmada, termal otel işletmelerindeki personel bulma, seçme ve personeli işe yerleştirme süreçlerinde yaşanan sorunların da araştırma boyunca değinilen turizm literatüründeki araştırma sonuçlarıyla genelde benzerlik gösterdiği ve özellikle termal otel işletmesine has bazı özelliklerden dolayı bazı farklılıklar da taşıdığı araştırmadan çıkan bulgular arasındadır.

Araştırmanın; otel işletmelerinde personel bulma, seçme ve personeli işe yerleştirme kapsamında geçmişte yapılan birçok araştırma sonuçlarını derleyen ve kendi sonuçlarıyla karşılaştıran bir yapıda olması sebebiyle, gelecekte; araştırmacılara bu konu dâhilinde üzerinde çalışılacak araştırma konularına ilişkin öneriler sunmakta fayda görülmektedir. Söz konusu öneriler aşağıda sunulmuştur:

- Bu kapsamda öncelikle belirtilebilir ki, özellikle konuyla ilgili literatürde, genellikle ve ağırlıklı olarak personel bulma ve seçme üzerine çalışmaların yapılması; personeli işe yerleştirme sürecinin önemsiz bir süreç gibi değerlendirilmesine yol açmaktadır. $\mathrm{Bu}$ doğrultuda ilk olarak personeli işe yerleştirme sürecinde yaşanan sorunlar üzerine yapılacak bir araştırma konusu önerilebilir. 
- Diğer bir araştırma önerisini ise bu süreçte en çok sorunun yaşandığı turizm işletmesi olan konaklama işletmelerinin bu araştırmada olduğu gibi kendi içinde ayrılan işletme türlerine indirgenerek; daha spesifik bir çalışma konusunun oluşturulabildiği, sorunların daha spesifik değerlendirilmesinin sağlanabildiği ve karşılaştırmaların yapılabildiği araştırmaların tasarlanması oluşturmaktadır.

- Bir diğer araştırma önerisi olarak insan kaynakları departmanının bu süreçte ne kadar etkin rol aldığının belirlenmesi açısından turizm işletmelerinde mevcut durumun tespitine yönelik insan kaynakları departmanı yöneticileri üzerinde araştırmalar gerçekleştirilmesi önerilebilir.

- Başka bir araştırmada ise otel işletmelerinde son yıllarda daha fazla rağbet gören Türkiye İş Kurumu aracılığı ile bulunan personel ile diğer kaynaklardan bulunan personel arasındaki nitelik, işe uygunluk, başarı vb. unsurları karşılaştırılabilir.

- Son olarak ise termal otel işletmelerinin çalıştırdığı sağlık personelini bulma, seçme ve personeli işe yerleştirme süreçleri detaylı incelenerek işletmelerin ve sağlık personelinin bu süreçlerdeki tutum ve memnuniyetlerinin tespiti üzerine bir araştırma önerilmektedir.

Termal otel işletmelerinde yapılan bu araştırma ışığında personel bulma, seçme ve personeli işe yerleştirme sürecine otel işletmeleri tarafından daha fazla önem verilmesi gereğinin yanında, bu süreçte daha profesyonel ve verimli uygulamalara başvurulması gerekliliği ortaya konmuştur. Bu gerekliliklerin hem Afyonkarahisar'daki termal otel işletmelerinin hizmet kalitesinin yükseltilmesinde hem de personel ve personel adaylarıyla ilgili olan birtakım sorunlarının (işletmeyi veya ücreti beğenmeme, işletmeye aidiyet duygusunun olmaması vb.) çözümünde etkin rol oynadığı unutulmayarak araştırma dâhilindeki otel işletmelerinin bu kapsamda olumlu yönde bir değişime gitmeleri tavsiye edilmektedir.

\section{Kaynakça}

Acar, A. C. (2010), 'İnsan Kaynakları Planlaması ve İşgören Seçimi', İçinde İnsan Kaynakları Yönetimi, 5. Baskı, ss. 85-160, İstanbul: Beta Yayınları.

Adıgüzel, O. (2009), 'Personel Seçiminin Analitik Hiyerarşi Prosesi Yöntemiyle Gerçekleştirilmesi', Dumlupınar Üniversitesi Sosyal Bilimler Dergisi, (24), ss. 243-252.

Akbaba, A. ve Günlü, E. (2011), 'Otel İşletmelerinde Personel Bulma, Seçme ve Eğitim Sürecinin Stratejik İnsan Kaynakları Bakış Açısıyla Değerlendirilmesi: Beş Yıldızlı Otellerde Bir Araştırma', Sosyal ve Ekonomik Araştırmalar Dergisi, 16(22), ss. 199-229.

Akoğlan, M. (1998), 'Turizm Sektöründe İnsan Kaynakları Seçim Yöntemleri', Anatolia: Turizm Araştırmaları Dergisi, 9(1), ss. 26-30.

Akova, O., Sarışık, M., ve Akbaba, A. (2007), 'Seyahat Acentalarında İşgören Bulma ve İşgören Seçme Yöntemlerine Yönelik Bir Araştırma', Karamanoğlu Mehmetbey Üniversitesi Sosyal ve Ekonomik Araştırmalar Dergisi, (2), ss. 275296.

Akova, O., Tanrıverdi, H. ve Kahraman, O. C. (2015), 'Otel İşletmelerinde Personel Devir Hızına Etki Eden Risk Faktörlerinin Belirlenmesine Yönelik Bir Araştırma', Süleyman Demirel Üniversitesi Vizyoner Dergisi, 6(12), ss. 87-107.

Armstrong, M. ve Taylor, S. (2014), Armstrong's Handbook Of Human Resource Management Practice, 13. Baskı, London: Kogan Page Publishers.

Aslan, Z. (2015), 'Termal Turizm İşletmelerinde Hizmet Standartları', Turizm-Sağıık ve Hukuk Sempozyumu İçinde (ss. 23-42), Nevşehir: Hacı Bektaş Veli Üniversitesi. 
Atoyan, K. (2015), 'Characteristics of Human Resources Management in Tourism Industry of Republic of Armenia', Int'l Conference on Business, Marketing \& Information System Management İçinde (ss. 1-4), Paris.

Ayan, F. (2011), Insan Kaynakları Yönetimi, İzmir: İlya İzmir Yayınevi.

Bilgiçli, İ. (2010), Turizm İşletmelerinin Personel Tedarikinde Türkiye İş Kurumu'nun Etkinlik Düzeyinin Belirlenmesi: İstanbul'da Bir Alan Araştırması, Yayınlanmamış Yüksek Lisans Tezi, T.C. Sakarya Üniversitesi, Sosyal Bilimler Enstitüsü, Sakarya.

Boz, C. (2006), Dünya'da Turizm Endüstrisinde İstihdam ve Çalışma Şartları, Yayınlanmamış Yüksek Lisans Tezi, T.C. Marmara Üniversitesi, Sosyal Bilimler Enstitüsü, İstanbul.

Burke, R. J. ve Ng, E. (2006), 'The Changing Nature of Work and Organizations: Implications for Human Resource Management', Human Resource Management Review, 16(2), ss. 86-94.

Chan, S. H. ve Kuok, O. M. (2011), 'A Study of Human Resources Recruitment, Selection, and Retention Issues in the Hospitality and Tourism Industry in Macau', Journal of Human Resources in Hospitality \& Tourism, 10(4), ss. 421441.

Chien, C. F. ve Chen, L. F. (2008), 'Data Mining to Improve Personnel Selection and Enhance Human Capital: A Case Study in High-Technology Industry', Expert Systems with Applications, 34(1), ss. 280-290.

Cho, S., Woods, R. H., Jang, S. S. ve Erdem, M. (2006), 'Measuring the Impact of Human Resource Management Practices on Hospitality Firms' Performances', International Journal of Hospitality Management, 25(2), ss. 262-277.

Çabuk, S. (2005), Otel İşletmelerinde Personel Seçimi ve Bir Alan Çalışması, Yayınlanmamış Yüksek Lisans Tezi, T.C. Balıkesir Üniversitesi, Sosyal Bilimler Enstitüsü, Balıkesir.

Çavdar, H. ve Çavdar, M. (2010), 'İşletmelerde Personel Bulma ve Seçme Aşamaları', Journal of Naval Science and Engineering, 6(1), ss. 79-93.

Çolak, A. (2010), 'İnsan Kaynağını Bulma ve Seçme' İçinde U. Dolgun (Editör), İnsan Kaynakları Yönetimi, ss. 85-110, Bursa: Ekin Yayınevi.

Demir, M. (2011), 'İş Yaşamında Ayrımcılık: Turizm Sektörü Örneği', Uluslararası İnsan Bilimleri Dergisi, 8(1), ss. 760-784.

Dessler, G. (2013), Human Resource Management, 13. Baskı, Upper Saddle River: Pearson Prentice Hall.

Dias, L. P. (2011), Beginning Management of Human Resources, Washington, DC: Flat World Knowledge Book.

Erdem, B. (2002), Otel İşletmelerinde İnsan Kaynakları Yönetimi Açısından Personel Bulma ve Seçme Süreci (Örnek Bir Uygulama), Yayınlanmamış Yüksek Lisans Tezi, T.C. Balıkesir Üniversitesi, Sosyal Bilimler Enstitüsü, Balıkesir.

Erdem, B. ve Gezen, T. (2014), 'Turizm İşletmelerine Yönelik İş İlanlarının İçerik Analizi Yöntemiyle İncelenmesi', Uluslararası Yönetim İktisat ve İşletme Dergisi, 10(21), ss. 19-42.

Erdem, B., Gülcan, B. ve Chykynov, S. (2015), 'Konaklama İşletmelerinde Spa \& Wellness Hizmetlerinde Çalışan İşgörenlerin Profili: Antalya'daki Beş Yıldızlı Otel İşletmelerinde Bir Araştırma', Akademik Bakış Dergisi, (48), ss. 238-257.

Erdil, O. ve Özutku, H. (2013), Insan Kaynakları Yönetimi, İstanbul: Lisans Yayıncılık.

Gümüş, Ş., Arı, M. ve Bakırtaş, H. (2010), 'Otel İşletmelerinde Personel Seçimi: Bursa İlinde Bir Uygulama', Ulusal Meslek Yüksekokulları Öğrenci Sempozyumu İçinde (ss. 1-12), Düzce Üniversitesi.

Karacaoğlu, K. (2013), 'İşgören Temini ve Seçimi', İçinde O. Erdil ve H. Özutku, (Editörler), Insan Kaynakları Yönetimi, ss. 167-195, İstanbul: Lisans Yayıncılık. 
Keskin, G. (1998), 'Doğu Anadolu Bölgesi'nde Bulunan Turizm İşletme Belgeli Otellerin Personel ve Hizmet Kalitesinin Değerlendirilmesi', Anatolia: Turizm Araştırmaları Dergisi, 9(1), ss. 44-50.

Kolu, N. (2006), Otel İşletmelerinde İnsan Kaynakları Seçim Yöntemleri Personel Bulma ve Seçme Süreci (Örnek Bir Uygulama), Yayınlanmamış Yüksek Lisans Tezi, T.C. Sakarya Üniversitesi, Sosyal Bilimler Enstitüsü, Sakarya.

Kozak, M. A. (2009), Otel İşletmelerinde İnsan Kaynakları Yönetimi ve Örnek Olaylar, 3.Baskı, Ankara: Detay Yayıncılık.

Kök, M. (2013), Sağlık Turizmi Açısından Termal Turizm (Denizli Örneği), Yayınlanmamış Yüksek Lisans Tezi, Beykent Üniversitesi, Sosyal Bilimler Enstitüsü, İstanbul.

Mathis, R. L. ve Jackson, J. H. (2008), Human Resource Management, 12. Baskı, Mason: Thomson South-Western.

Mathis, R. L. ve Jackson, J. H. (2011), Human Resource Management, 13. Baskı, Mason: South-Western Cengage Learning

Nickson, D. (2007), Human Resource Management for the Hospitality and Tourism Industries, Burlington: Elsevier.

Örücü, E. (2002), 'Turizm İşletmelerinde Orta ve Üst Kademe Yöneticilerin Personel Seçme ve Değerlendirme Sürecindeki Eğilimleri (Marmaris ve Çevresindeki Üç Yıldızıı İşletmeler Örneği)', Dokuz Eylül Üniversitesi Iktisadi ve Idari Bilimler Dergisi, 17(2), ss. 119-132.

Özbek, T. (1991), 'Dünya'da ve Türkiye'de Termal Turizmin Önemi', Anatolia: Turizm Araştırmaları Dergisi, 2(3), ss. 15-29.

Özdemir, S. S., Polat, E. ve Met, Ö. L. (2015), 'Bodrum'da Faaliyet Gösteren Konaklama İşletmelerince Verilen İş İlanlarındaki Personel Niteliklerinin Analizi', Muğla Sıtkı Koçman Üniversitesi Sosyal ve Beşeri Bilimler Araştırmaları Dergisi, (34), ss. 121-138.

Özgan, B. B., Yazıcı, H. N. T. ve Fener, T. Ç. (2010), 'Turizm İşletmelerinde Teknik Hizmetler Biriminin (Bölümünün) Personel Seçme, Değerlendirme ve İşe Yerleştirme Süreci, Kurum İşleyiş Sürecine Etkisi (Örnek Çalışma: Çırağan Kempinski Oteli)', Organizasyon ve Yönetim Bilimleri Dergisi, 2(2), ss. 29-35.

Pelit, E. (2015), 'Turizm İşletmelerinde İnsan Kaynakları Yönetiminin Önemi' İçinde E. Pelit (Editör.), Turizm İşletmelerinde Insan Kaynakları Yönetimi, ss. 61-116, Ankara: Grafiker Yayınları.

Pelit, E. ve Kılıç, İ. (2012), 'Mobbing ile Örgütsel Bağlılık İlişkisi: Şehir ve Sayfiye Otellerinde Bir Uygulama', İşletme Araştırmaları Dergisi, 4(2), ss. 122-140.

Şenyücel, Z. (2009), Managing Human Resource on 21st Century, London: London Ventus Publishing APS.

Şimşek, A., Catır, O. ve Ömürbek, N. (2014), 'Turizm Sektöründe Bulanık Analitik Hiyerarşi Süreci ile Personel Seçimi', Uludağ Üniversitesi Iktisadi ve İari Bilimler Fakültesi Dergisi, 33(2), ss. 147-169.

Şit, M. (2016), 'Türkiye'de Turizm Sektörünün İstihdama Katkısı', Akademik Yaklaşımlar Dergisi, 7(1), ss. 101-117.

T.C. Kültür ve Turizm Bakanlığı (2016). 'Turizm Tesisleri', http://yigm.kulturturizm.gov.tr/TR,9579/turizm-tesisleri.html (25.06.2016).

Tekin, Ö. A. ve Tüfekçi, Ö. K. (2015), 'Turizm Öğrencilerinin Sendika Algısı: Üniversite Öğrencileri Üzerine Bir Araştırma', Afyon Kocatepe Üniversitesi Sosyal Bilimler Dergisi, 17(1), ss. 171-200.

Temizkan, R. (2010), Personel Seçim Sürecinde İş Başvuru Formlarında Ayrımcılık: Konaklama İşletmelerinde Bir Uygulama, Yayınlanmamış Doktora Tezi, T.C. Gazi Üniversitesi, Sosyal Bilimler Enstitüsü, Ankara. 
Temizkan, R. (2015), 'Turizm İşletmelerinde İnsan Kaynakları Bulma-Seçme ve İşe Alma' İçinde E. Pelit (Editör), Turizm Iş̧letmelerinde Insan Kaynakları Yönetimi, ss. 239-286, Ankara: Grafiker Yayınları.

Tütüncü, Ö. ve Demir, M. (2002), Konaklama İşletmelerinde Insan Kaynakları Yönetimi ve Insan Gücü Hareketleri Analizi, Ankara: Turhan Kitapevi.

Ünal, Ş. (2006), İnsan Kaynaklarında Tedarik Eğilimleri ve İzmir İli Seyahat Acentaları Uygulaması, Yayınlanmamış Yüksek Lisans Tezi, T.C. Dokuz Eylül Üniversitesi, Sosyal Bilimler Enstitüsü, İzmir.

Yeşiltaş, M. (2015), 'Turizm İşletmelerinde Endüstri ve Sendika İlişkileri' İçinde E. Pelit (Editör), Turizm Işsetmelerinde Insan Kaynakları Yönetimi, ss. 453-497, Ankara: Grafiker Yayınları.

Yeşiltaş, M., Arslan, Ö. E. ve Temizkan, R. (2012), 'Personel Seçiminde ve Örgüt İçi İş Yaşamında Siyasi Ayrımcılık: Otel İşletmelerinde Bir Araştırma', Iş̧letme Araştırmaları Dergisi, 4(1), ss. 94-117.

Yeşiltaş, M., Temizkan, R. ve Temizkan, P. (2010), 'Türkiye'deki Konaklama İşletmelerinin İş Başvuru Formlarında Ayrımcılık', Ticaret ve Turizm Eğitim Fakültesi Dergisi, (2), ss. 180-197. 